\title{
The Correlation Between Body Mass Index (BMI) and Belly Circumference and Hypertension Occurence on Elderly in Tulungagung, Indonesia
}

\author{
Devi Wulandari ${ }^{1}$ \\ Universitas Negeri Malang \\ Malang, Indonesia \\ pood87@yahoo.com
}

\author{
Hartati Eko Wardani² \\ Universitas Negeri Malang \\ Malang, Indonesia \\ hartati.eko.fik@um.ac.id
}

\author{
Rara Warih Gayatri ${ }^{*}$ \\ Universitas Negeri Malang \\ Malang, Indonesia \\ rara.warih.fik@um.ac.id
}

\begin{abstract}
Hypertension causes the highest death in Indonesia namely in the amount of $37 \%$. The highest category suffers from hypertension in Indonesia is at age $\mathbf{6 5 - 7 5}$ years old namely $26,7 \%$ - 27,9\%. Hypertension is the increase of systolic blood pressure more than $140 \mathrm{mmHg}$ and diastolic pressure more than $90 \mathrm{mmHg}$ in two times measurement. Many factors can cause hypertension such as BMI and belly circumference. The purpose of this research is to find out the correlation between Body Mass Index (BMI) and belly circumference and hypertension occurrence on eldery age 55-75 years old at Integrated Service Post (Posyandu) Ngujang work area of Community Health Center (Puskesmas) Simo Tulungagung Regency, Indonesia. The sampling technique used in this research was simple random sampling and obtained respondents in the amount of 50 elderly. This research was conducted by measuring the body weight, body height, and belly circumference. The technique of data collection in this research was by doing observation using instruments such as card book heading to healthy elderly (to find out the hypertension status), weight scales, microtoice and medline. Data analysis techniques used in this research were univariate using percentage and bivariate using chi square test $\left(x^{2}\right)$ with $\alpha=0,05$. The results in this research show that there is significant correlation between $\mathrm{BMI}$ and hypertension occurrence $(p$-value $=0,42,>0,05)$ and belly circumference obtained p-value $0,047<0,05$ then there is significant correlation between belly circumference and hypertension occurrence. This research suggests that routine check needs to be done in anthropometry balanced with nutrients intake and suitable physical exercise to gain ideal body proportion.
\end{abstract}

Keywords_hypertension, elderly, Body Mass Index, Belly Circumference.

\section{INTRODUCTION}

Hypertension is the increase of systolic blood pressure more than $140 \mathrm{mmHg}$ and diastolic blood pressure more than 90 $\mathrm{mmHg}$ in two times measurement with time range five minutes in calm condition or enough rest [1]. Hypertension becomes the main risk factor of heart disease and stroke [2]. Different symptoms on each individual cause hypertension called as the silent killer [1]. Those symptoms are headache, heart palpitations, blurred vision, ringing in the ears, and nosebleed [2]. The group with the highest risk who mostly suffers from hypertension is the community age 65-75 years old [3].

East Java experiences increase of hypertension prevalence until 3\% [4]. In Tulungagung Regency, hypertension always becomes the five big diseases mostly sufferred, namely 21.214 people in 2015 and increases drastically to be 322.637 people in 2017 . In work area of Simo Community Health Center, there were 1569 hypertension cases [5]. One of risk factors of hypertension is obesity which can be measured through Body Mass Index (BMI) and belly circumference. According to the research results found that the hypertension patient can be found more on central obesity people [6]. Many abdominal fat heap increases vascular resistance in improving the heart work to pump the blood to all over the body [6]. From the result of preliminary research at Community Health Center Simo Tulungagung Regency, Indonesia, it was found that the community did not really understand the importance of BMI and Belly Circumference check routinely at Community Health Center (Simo Community Health Center, 2018). Therefore, the purpose of this research is to find out the correlation between BMI and belly circumference and hypertension occurrence on elderly in Tulungagung, Indonesia.

\section{METHOD}

This research used quantitative method with observational analytics survey through cross sectional approach. The population in this research was elderly age 55-75 years old coming to Posyandu Ngujang work area of Puskesmas Simo, Tulunggagung, Indonesia. The sampling technique used in this research was simple random sampling and obtained 50 elderly as respondents. The inclusion criteria in this research were male or female age 55-75 years old and willing to be respondents. While, for the exlusion criteria were pregnant women, athlete, and patients who were taking antihypertension medicine. This research was conducted by measuring the body weight, body height, and belly circumference. The 
techniques of data collection in this research were through observation using the instruments such as card book heading to healthy elderly (to find out the hypertension status), body weight scales, microtoise, and medline. Data analysis techniques used for this research were univariate using percentage and bivariate using chi square test $\left(\mathrm{x}^{2}\right)$ with $\alpha=0,05$.

\section{RESULT}

The following is the characteristics of respondents who become the research subjects and the result of BMI analysis and belly circumference towards hypertension occurrence at Posyandu Ngujang, Puskesmas Simo, Tulungagung Regency, Indonesia.

TABLE 1. THE CHARACTERISTICS' DESCRIPTION OF RESEARCH RESPONDENTS

\begin{tabular}{|c|c|c|}
\hline Type of Variable & $\begin{array}{c}\text { Total } \\
(\mathbf{N}=\mathbf{5 0})\end{array}$ & Percentage (\%) \\
\hline \multicolumn{3}{|c|}{ Gender } \\
\hline Female & 39 & $78 \%$ \\
\hline Male & 11 & $22 \%$ \\
\hline \multicolumn{3}{|c|}{ Educational Level } \\
\hline Never School & - & - \\
\hline Not Graduated from Elementary School & 9 & $18 \%$ \\
\hline Primary Education & 28 & $56 \%$ \\
\hline Secondary Education & 11 & $22 \%$ \\
\hline Higher Education & 2 & $4 \%$ \\
\hline \multicolumn{3}{|l|}{ Occupation } \\
\hline Unemployed & 12 & $24 \%$ \\
\hline Housewife (IRT) & 11 & $22 \%$ \\
\hline Merchant & 12 & $24 \%$ \\
\hline Civil Servant (PNS) & 3 & $6 \%$ \\
\hline Farmer & 7 & $14 \%$ \\
\hline Private & 5 & $10 \%$ \\
\hline $\begin{array}{c}\text { Hypertension Category } \\
\text { Yes } \\
\text { No }\end{array}$ & 23 & $46 \%$ \\
\hline & & \\
\hline
\end{tabular}

Based on table 1.1, it can be seen that the distribution of gender frequency from 50 respondents obtain in the amount of 39 people $(78 \%)$ female and the rest is male. The respondents' frequency distribution based on educational level obtains that out of 50 elderly, 9 people (18\%) never graduate from Elementary School and in the amount of 28 people $(56 \%)$ graduate from elementary school. Meanwhile, there were 11 people $(22 \%)$ had middle education, and 2 people $(4 \%)$ had higher education. The respondents' frequency distribution based on occupation obtains that 12 people $(24 \%)$ were merchants, 3 people (6\%) worked as Civil Servant (PNS) or retired from PNS, 7 people $(14 \%)$ worked as farmer, and 5 people $(10 \%)$ private sector. The respondents' hypertension status obtained data that there were 23 people (46\%) suffering from hypertension and 27 people $(54 \%)$ did not experience hypertension.

TABLE 2. THE BIVARIATE ANALYSIS RESULT BETWEEN BMI AND BELLY CIRCUMFERENCE TOWARDS HYPERTENSION OCCURRENCE AT POSYANDU NGUJANG WORK AREA OF PUSKESMAS SIMO TULUNGAGUNG REGENCY

\begin{tabular}{lccc}
\hline \multicolumn{1}{c}{ Variable } & $\mathbf{R P}$ & $\boldsymbol{p}$-value \\
\hline V1 Body & Mass $\quad$ Index & 0,$889 ; 0,889 ; 2,333 ;$ & 0,420 \\
(IMT) & 1,$444 ; 2,591$ & \\
V2 Belly Circumference & $0,409^{*}$ & 0,047 \\
\hline
\end{tabular}

This sign $(*)$ shows significant correlation $(\mathrm{p}<0,05)$

Based on table 2 obtains data that there is no significant correlation between Body Mass Index (BMI) and hypertension occurrence at Posyandu Ngujang Work Area of Puskesmas Simo, Tulungagung Regency, Indonesia, with $\mathrm{p}$-value in the amount of $0,420$ ( $p>0,05)$. Beside that, obtained the Ratio Prevalence value (PR) in the amount of 0,$889 ; 2,333 ; 1,444 ; 2,591$ (PR value in this variable has no meaning because there is no significant correlation between Body Mass Index (BMI) and the occurrence). And for belly circumference variable obtains $p$-value in the amount of 0,047 $(p<0,05)$, showing that there is significant correlation between belly circumference and hypertension occurrence at Posyandu Ngujang work area of Puskesmas Simo Tulungagung Regency, Indonesia. Beside that, obtained Ratio Prevalence (RP) in the amount of 0,409 which shows that the people who have abnormal belly circumference (obesity) get chance to have hypertension risk in the amount of 0,409 times compared to the people with normal circumference.

\section{DISCUSSION}

\section{A. The Correlation Between Body Mass Index (BMI) and Hypertension Occurrence \\ Based on chi square statistics test obtained $p$-value in the} amount of $0,420(p>0,05)$, showing that there is no significant correlation between Body Mass Index (BMI) and hypertension occurrence at Posyandu Ngujang work area of Puskesmas Simo. Beside that, obtained Ratio Prevalence (RP) value in the amount of 0,$889 ; 2,333 ; 1,444 ; 2,591$ (PR value in this variable has no meaning because there is no significant correlation between Body Mass Index (BMI) and hypertension occurrence at Posyandu Ngujang work area of Puskesmas Simo. This is in line with the research conducted by Suhangga who states that there is no significant correlation between Body Mass Index and hypertension on hypertension patients at Education Hospital of Hasanuddin University [7]. This research is also in accordance with the other research results conducted at Samosir Village in 2016 by Arifin et. al., that there is no meaningful correlation between nutrition status and hypertension occurrence [8]. Body mass index also have correlation between high blood pressure prevalence in the older adults and hypertension occurence [9].

However, the result of this research is not in line with the research by Estiningsih, that there is significant correlation between BMI and hypertension occurrence. In her research, the respondents who have BMI more than normal, obtain hypertension risk 2,626 times bigger than the respondents who have normal BMI [10]. Obesity in a number of research correlates to hypertension because in the fat body will need higher oxygen and will increase heart work. Beside that, obesity will be followed by excessive body fat level mainly on abdominal obesity that is risky towards hypertension and other degenerative diseases [10].

In this research results non meaningful correlation, the BMI average from respondents is 27,53 which is included into obesity but for further investigation about IMT correlation with hypertension can be seen other correlated factors such as lifestyle, salt intake, physical activity, family history, stress, and ethnique. The body difference in receiving the salt intake and controlling the hormone in blood, the people who do not to physical activities tend to be riskier of hypertension [11] [12]

\section{B. The Correlation Between Belly Circumference and Hypertension Occurrence}

The result of chi square statistics test obtains p-value in the amount of $0,047(p<0,05)$ which shows that there is significant correlation between belly circumference and hypertension occurrence at Posyandu Ngujang work area of Puskesmas Simo Tulunggagung Regency. Beside that also obtained the Ratio Prevalence (RP) 0,409 which shows that the people who have abnormal (obesity) belly 
circumference has the opportunity of hypertension risk in the amount of 0,409 times compared to people who have normal belly circumference. According to Mafaza et. al., hypertension occurs more on respondents with central obesity belly circumference, while the respondents who do not experience central obesity many of them do not suffer from hypertension [13]. The mechanism of central obesity can cause hypertension related to the hyperinsulinemia condition and the presence of vascular structure damage. In central obesity, the fat gathers in the form of visceral fat accumulated in abdomen, if the visceral fats are too much and there is decrease of leptin sensitivity, and there is sitokin which infiltrates the fat tissue, then there will be increase of intracell free fat acid which can direct to the occurrence of hyperinsulinemia and insuline resistance. When insuline resistance occurs, then nitrit oxide decreases, until vasolilatasi vascular occurs, salt sensitivity occurs, and increase of plasma volume altogether will cause the increase of blood pressure or hypertension [13]. The same result have been Yunita and Ratu, changes in waist circumference (central obesity) in the elderly are caused by changes in weight, fiber consumption, number of chronic diseases and physical activity beginning at the pre-elderly stage. Normal weight, high fiber consumption, absence of chronic diseases and physical activity for more than $30 \mathrm{~min}$ a day should be maintained beginning in the pre-elderly stage to ensure a normal waist circumference in the elderly stage [14]. Waist Circumference is associated with hypertension prevalence independent of body mass index and several hypertension risk factors in middle-aged and older adults [15].

\section{CONCLUSION}

Based on the research results, it can be concluded that:

1. There is no significant correlation between Body Mass Index (BMI) and hypertension occurrence at Elderly Posyandu Ngujang work area of Puskesmas Simo Tulungagung Regency with p-value $=0,420$.

2. There is significant correlation between belly circumference with hypertension occurrence at Elderly Posyandu Ngujang work area of Puskesmas Simo Tulungagung Regency with pvalue 0,047

\section{SUGGESTION}

After finding out the risk factors of hypertension, it is expected that Health Department of Tulungagung Regency can enlarge the health promotion target and conducts screening on the productive age, and the community has the awareness to check themselves routinely to the available health facility. Beside that it is important to have physical training until obtained ideal body proportion to avoid the hypertension risk.

\section{REFERENCES}

[1] 2014a Kemenkes RI, "Hipertensi," 2014

[2] dkk Dalimartha, Care Your Self, HIPERTENSI. Jakarta: Penerbit Penebar Plus, 2008.

[3] Dinas Kesehatan Republik Indonesia, "Riset Kesehatan Dasar," Diabetes Mellit., pp. 87-90, 2013, doi: 1 Desember 2013.

[4] K. RI, "Buletin Jendela Data dan Informasi Kesehatan Penyakit Tidak Menular." 2013.

[5] D. K. Tulungagung, "Profil Kesehatan Tulungagung 2017," 2017.

[6] D. Wongkar, "Hubungan indeks massa tubuh dan lingkar pinggang dengan tekanan darah pada mahasiswa fakultas kedokteran universitas sam ratulangi 1," vol. 2, 2014.

[7] G. I. Suangga, "Hubungan Indeks Massa Tubuh dengan Hipertensi di Rumah Sakit Pendidikan Universitas Hasnuddin," 2017.

[8] M. Bin Mohd Arifin and I. Weta, "Faktor-Faktor Yang Berhubungan Dengan Kejadian Hipertensi Pada Kelompok Lanjut Usia Di Wilayah Kerja Upt Puskesmas Petang I Kabupaten Badung Tahun 2016," E-Jurnal Med. Udayana, vol. 5, no. 7, 2016.

[9] Y. H. Song, "The association of blood pressure with body mass index and waist circumference in normal weight and overweight adolescents," Korean J. Pediatr., vol. 57, no. 2, pp. 79-84, 2014, doi: 10.3345/kjp.2014.57.2.79.

[10] Estiningsih, "Hubungan Indeks Massa Tubuh Dan Faktor Lain Dengan Kejadian Hipertensi Pada Kelompok Usia 1844 Tahun Di Kelurahan Sukamaju Depok Tahun 2012," Karya Ilm., vol. 127, no. 3, pp. 287-301, 2012.

[11] A. D. Ramadhani, "Hubungan Kontrol Tekanan Darah dengan Indeks Massa Tubuh Pasien Hipertensi,” 2013.

[12] W. Zhang et al., "Association of body mass index and waist circumference with high blood pressure in older adults," BMC Geriatr., vol. 21, no. 1, pp. 1-10, 2021, doi: 10.1186/s12877-021-02154-5.

[13] R. L. Mafaza, B. Wirjatmadi, and M. Adriani, "Analisis Hubungan Antara Lingkar Perut, Asupan Lemak, Dan Rasio Asupan Kalsium Magnesium Dengan Hipertensi," Media Gizi Indones., vol. 11, no. 2, p. 127, 2018, doi: 10.20473/mgi.v11i2.127-134.

[14] J. Yunita and R. Ayu Dewi S, "Waist Circumference for Central Obesity Detection from the Pre-Elderly Stage to the Elderly Stage in Indonesia: A Longitudinal Study," Pakistan J. Nutr., vol. 18, no. 4, pp. 379-386, 2019, doi: 10.3923/pjn.2019.379.386.

[15] M. G. T. and J. F. S. Wager, "Moderate Waist Circumference and Hypertension Prevalence: The REGARDS Study," Bone, vol. 23, no. 1, pp. 1-7, 2011, doi 10.1038/ajh.2010.258.Moderate. 